\title{
Physico-chemical Properties, Uric acid, Carbohydrates, Mineral, Trypsin Inhibitor Activity and Phytic Acid Content of Bruchids Infested Processed Chick Pea
}

\author{
Rajni Modgil", Ratni Devi, Archana Sood and Anupama Sandal \\ Department of Food Science, Nutrition and Technology, College of Community Science \\ CSKHPKV Palampur, India \\ *Corresponding author
}

A B S T R A C T

Keywords

Insect infestation, Weight, Chick pea, Cooking, Uric acid, Energy value, Starch, Anti nutritional factors,

Article Info

Accepted:

17 January 2021

Available Online:

10 February 2021
Chick peas, a legume crop grown in temperate and semiarid climatic condition is heavily infested by bruchids during storage, which results in the qualitative as well as quantitative loses. Insect infested legumes are consumed by unaware people after cooking because insects are not visible although the larval and pupil stages of insects are inside the grains. Holes in grains are only visible when adult insect comes out of the grain Present study was planned to evaluate physico - chemical properties, uric acid, carbohydrates, mineral, trypsin inhibitor activity and phytic acid content of processed bruchids infested chick pea at the graded levels of bruchids infestation (20,40 and 60\%). The results revealed that with increase in the level of infestation, significant increases $(\mathrm{p} \leq 0.05)$ was observed in all the parameters, except for decreases in weight content density embedded larvae carbohydrates and true protein. Even cooking of insect infested chick pea could not improve the quality of legume. Only slight decrease was noted in uric acid phytic acid and trypsin inhibitors of Chick pea after cooking presence of insect excreta and body parts, legumes becomes unhygienic and should not be consumed even after processing.

\section{Introduction}

Chick pea is light colored, larger seed size having smooth and thin skin as compared to Bengal gram (ICRISAT, 1993). This legume is grown mainly in areas with temperate and semiarid climate. It is mainly grown in Southern Europe, Northern Africa, Afghanistan and Chile, also introduced during the 18th century to the Indian subcontinent. Legume is widely used as protein rich supplement to achieve better health in developing countries. India is one of the major pulse producing countries accounting for about 27-28 percent of world Legumes production. Legumes are grown widely throughout India during Rabi and kharif seasons. Area under pulse cultivation has been fluctuating between 22-24 million hectares.

Chick pea is a nutritious pulse providing about 360 calories, $17.1 \mathrm{~g}$ proteins, $3-5 \mathrm{~g}$ fat and $10.2 \mathrm{mg}$ iron per 100g (Gopalan 2010). 
The Legume is usually stored for a longer period or until the harvest of the next crop. Legumes are susceptible to infestation, both in the field and during storage, by weevils, which are prolific, breed rapidly, and cause serious deterioration in the nutritive value of the grain. Deterioration of legumes during storages occurs due to various physical, chemical and biological factors. These are temperature, humidity, storage structure, micro-organism, fungi, insects, rodents and birds. The losses during post harvest handling and storage are up to the extent of 8.5 per cent of total production (Khader, 2000). During storage of legumes bruchids infestation is very common problem. Bruchids harbours certain pathogenic micro organisms which cause food poisoning and food spoilage (Neergaurd and Kumari, 1983). This results not only in quantitative losses, but qualitative losses as well (Ratni et al., 2019).

Infested grains are likely to contain living insects in different stages of development, their body fragments and excreta make the pulse unhygienic (Swaminathan, 1977); (Modgil and Mehta, 1996). Uric acid is one of the excretory end products of insects. When consumed in excess may lead to gout. Insect infestation increases anti-nutritional factors like phytic acid, saponins and trypsin inhibitors in legumes (Modgil and Mehta, 1997). The most common methods for consumption of legumes are cooking which improve their nutritional and organoleptic qualities (Sangle et al., 1993, Mankotia and Modgil 2012).

The insect infestation results in quality deterioration including change in $\beta$-complex vitamin, protein, minerals and biological protein quality of legumes (Modgil, 2000). Insect infested Chickpea is consumed by unwary consumers after cleaning, washing and cooking. Work has been done on the nutritional quality of insect infested Chickpea but not much work has been reported on the effect of cooking on nutritional quality of insect infested Chickpea. So the present study was planned to see the effect of cooking on the physico chemical and nutritional quality of Chickpea at graded levels of infestation.

\section{Materials and Methods}

Chick pea (Cicer arietinum L.) was procured from the local market. The pulse beetle $C$. chinensis (L.) (Dhora) were obtained from the previously infected Chick pea and released in $500 \mathrm{~g}$ of Chick pea in a container covered with muslin cloth. Then the culture of $C$. chinenis was maintained at temperature $28 \pm 2^{\circ} \mathrm{C}$ and relative humidity of $75 \pm 2 \%$.

\section{Preparation of sample}

Chick pea was cleaned manually to get rid of dust/ other foreign materials and $1000 \mathrm{~g}$ sample was placed in triplicate in metallic air tight containers of $2 \mathrm{~kg}$ capacity. In each container, 80 pulse beetles irrespective of sex were released, covered with lids and kept for 28 days at room temperature $\left(27^{\circ}\right.$ to $\left.35^{\circ} \mathrm{C}\right)$. Depending upon climatic conditions, pulse beetle completes its life cycle in 23 to 28 days. The grains were first observed after 28 days, followed by 15 days interval, for obtaining desired levels of infestation (20, 40 and 60\%). the Legumes, along with containers, were deep frozen for $72 \mathrm{~h}$ to kill the adults as well as the developing insects. The insect debris and frass were removed manually and samples were stored in refrigerator toll further analysis. For determining embedded larvae percent 100 grains (in triplicate) were soaked overnight. Next morning, grains were subjected for dissection with the help of a very sharp blade so as to open the grains completely and total number of grains with larvae inside was calculated. 


\section{Cooking}

One hundred gram control and insect infested samples at different levels of infestation were soaked in water for six hours separately and then pressure cooked with equal amount of water for 30 minutes. The cooked samples were dried in cabinet tray drier at $50^{\circ} \mathrm{C} \pm 3^{\circ} \mathrm{C}$ for $12 \mathrm{~h}$. The cooked and uncooked samples of both varieties were milled separately in a Willy mill, to a fine powder so as to pass through a 40 mesh sieve. These samples were then kept in a refrigerator in air tight plastic containers till further analysis was done.

Color: The colour of the Chick pea grains were observed from their physical appearance through visual perception.

\section{Weight change}

Difference between initial weight and final weight of sample after infestation gave the weight change

Percent weight change $=$ Differences in the initial and final weight of sample/ initial weight of sample X 100

Density was determined by noting the change in water level (V) after adding one hundred grains (W)

Density $=$ Weight of legume grains / Rise in water level.

Per cent damaged grains was calculated by the formula, Number of pulse grains with holes x 100

Proximate constituents viz. moisture, ash, crude fat and crude fiber contents in the samples were determined by standard methods of AOAC (2010). Nitrogen was analyzed by Micro-kjeldhal AOAC (2010) and was multiplied by factor 6.25 for converting it into crude protein. The sugars in samples were also estimated by standard method of AOAC (2010). Total carbohydrates were calculated by the following formula:

Total carbohydrate $(\%)=100-($ Moisture + crude ash + crude protein + crude fat + crude fiber)

Energy in the samples was determined by chromic oxide method of O'Shea and Maguire (1962). Starch in finger millet was determined by the method of Clegg (1956). Non Protein Nitrogen (NPN) in samples was determined by the method of Pellet and Young (1980). Extraction of uric acid was conducted by method of AOAC (2010) and estimation was done by method of Oser (1971) Neutral detergent Fiber and Acid detergent Fiber in samples was estimated by the method of Van Soest and Wine (1967). Phytic acid was determined by the method of Davis and Reid (1979). Trypsin inhibitor activity in the samples was determined by the method given by Ray and Rao (1971). Phytate phosphorus was calculated by formula

Phytate phosphorus, $\mathrm{mg}=\mathrm{A} \times 28.18 / 100$. Where, $\mathrm{A}$ is the phytate content $(\mathrm{mg})$

Non phytate phosphorus was calculated as a difference between the total phosphorus and phytate phosphorus. The data from various laboratory experiments were subjected to statistical analysis for variance in a completely randomized design (Sendecor and Cocharn, 1968)

\section{Results and Discussion}

The weight, weight change, weight volume ratio, embedded larvae percent and, density decreased with level of infestation and a further decrease in these parameters was observed when insect infested grains were cooked (Table 1). Changes in cooked grains 
were higher which might be due to, during cooking larval and pupal stages of insects emerged out leaving behind mainly the husk portion, which is light in weight. Higher losses were noticed in the density of Chick pea after cooking some soluble nutrients leached out in water. Embedded larvae come out during cooking and reduction in weight is noted in grains. Decreases in the density of cooked Moth bean have been reported by Mankotia and Modgil (2012). Cooking resulted in a decrease in percent embedded larvae. This might have been due to reason that after cooking grains ruptured as result larvae and other insect stages might have been released in the cooking water. So the numbers of larvae inside the grains were less (Ratni et al., 2019).

Significant increase in proximate composition of insect infested grains was observed (Table 1). As the levels of infestation increased a significant $(\mathrm{P} \leq 0.05)$ increase was noted in the all the proximate constituents i.e. moisture, ash, protein, fat, crude fibre and total carbohydrate contents. Changes were minimum at $20 \%$ infestation level and maximum at $60 \%$ infestation level. A decrease in these constituents was noted after cooking except ash content and crude fiber content. Increase in the ash content of cooked insect infested grains might have been due to the reason that grains were cooked in tap water and water was not discarded. By the process of osmosis mineral content of water might have entered inside the grains. Similar results have been reported by Modgil (2002) and Mankotia and Modgil (2012). Increase in the crude protein content of uncooked insect infested grains of Chick pea at different level of infestation might have been due to the reason that insect (Callosobruchus chinensis L.) completes its larval and pupal stages inside the grains and even when adult insects emerged out their excreta is left behind in the cavity which causes an increase in crude protein. Modgil (2002) observed a significant increase in the crude protein content of insect infested uncooked Legumes at different level of infestation. This increase in crude fiber might have been due to the reason that insect C. chinensis has a tendency of consuming endosperm and germ portion of seeds which is rich in carbohydrates and husk portion rich in fiber is left behind. Increase in the crude fiber content of insect infested cooked grains of Chick pea might have been due to the reason that cooking of Legumes itself increases the crude fiber content which is due to formation of new protein fiber complex. Increase in fiber content of sound cooked grains of cowpea has been reported by Mankotia (2002) and Gupta (1995) they reported that cooking increase the crude fiber content of Legumes.

Insect infestation had an adverse effect on total carbohydrates, starch, energy, total sugars and non reducing sugars (Table 2). This decreased with increase in level of infestation and also with cooking. The highest starch, energy and carbohydrates $(52.90 \%$, $365 \mathrm{kcal} / 100 \mathrm{~g}$ and $60.11 \%$ ) was observed in control uncooked samples of Chick pea. Cooking of Chick pea at content also decreased due to utilization of carbohydrates for the growth of insects cooking of insect infested and uninfested legumes results in a decrease in the starch content, which might have been due to the reason that during cooking hydrolysis of starch initiated breakdown of complex carbohydrates into simpler forms. Losses in insect infested grains can be more due to reason that insect infestation deteriorates starch content in the seeds by the process of amylase activity (Kataria et al., 1990 and Jood, 1997).Cooking of insect infested Chick pea at different levels of infestation results in decrease in starch content. Decrease in the starch of uncooked insect infested Chick pea might have been due to the reason that insects have peculiar 
feeding habits insects consume mainly endosperm portion, rich in carbohydrates. As the levels of infestation increase, there is decrease in the calorific value of Chick pea. Earlier worker have also reported decrease in the starch and energy value of insect infested legumes Modgil and Mehta (1996); Samuel (1997). Cooking of insect infested legumes results in increase total sugar content of legumes which might have been due to the reason that during cooking bio-chemical changes take place as a result degradation of starch to glucose and maltose is there. Due to the process of glycolysis starch is converted to sugars. As the level of infestation increases there is a significant $(\mathrm{P} \leq 0.05)$ increase in the reducing sugar content. Cooking of insect infested legumes had non-significant difference in reducing sugar as compared with their uncooked counterparts. Insect infestation results in the decrease in non-reducing sugar content, whereas cooking of insect infested legumes results in the increase in nonreducing sugar content. The increase in nonreducing sugar content might have been due to insect infestation and also due to biochemical changes going on in stored grains. As insect population increased, there is increase in moisture content and sugars are converted to reducing form. Modgil and
Mehta (1995) have also reported that at higher level of infestation decrease in non-reducing sugars is there. Not much difference is observed in non-reducing sugar content of insect infested uncooked Chick pea. Non protein nitrogen was nil in control samples of uncooked and cooked grains. As the levels of infestation increased, total nitrogen and NPN also increased in uncooked grains. Total nitrogen ranged from 2.85-3.72 $\mathrm{g} / 100 \mathrm{~g}$, whereas NPN ranged from $0.002-1.98 \mathrm{~g} / 100 \mathrm{~g}$. True protein decreased with increase in the infestation levels. It ranged from 17.80 to 10.87 per cent. Cooking of insect infested Chick pea resulted in a significant $(p \leq 0.05)$ decrease in total nitrogen, non-protein nitrogen and true protein content. Uric acid, which is one of the major end products of protein metabolism in insects, increased significantly $(\mathrm{P}<0.05)$ with increase in level of infestation. There was a negligible amount of uric acid in uncooked control samples. As the levels of infestation increased, manifold increase in the uric acid was observed. In insect infested uncooked control samples the maximum uric acid content (3530.43 $\mathrm{mg} / 100 \mathrm{~g}$ ) was noted in Chick pea at 60 per cent infestation level. Cooking of insect infested grains of Chick pea resulted in a decrease in uric acid content.

Table.1 Effect of cooking on physico chemical characteristics at graded levels of insect (C. chinensis) infested Chick pea

\begin{tabular}{|c|c|c|c|c|c|c|c|c|c|}
\hline \multirow[t]{2}{*}{ Attribute } & \multicolumn{4}{|c|}{ Uncooked (Level of Infestation \%) } & \multicolumn{4}{|c|}{ Cooked (Level of Infestation \%) } & \multirow[t]{2}{*}{$\mathrm{CD}(\mathrm{p} \leq \mathbf{0 . 0 5})$} \\
\hline & 0 & 20 & 40 & 60 & 0 & 20 & 40 & 60 & \\
\hline Weight(gm) & 1000.00 & 1012.98 & 818.75 & 686.27 & 950.00 & 931.65 & 808.30 & 660.00 & 0.20 \\
\hline Weight change (\%) & 0 & +1.29 & -18.12 & -31.37 & -5.00 & -6.83 & -18.50 & -23.58 & - \\
\hline Density W(g)/V(m) & 1.86 & 1.98 & 1.63 & 1.42 & 1.08 & 0.92 & 0.89 & 0.71 & 0.06 \\
\hline $\begin{array}{l}\text { Embedded larvae } \\
(\%)\end{array}$ & 0 & 46.08 & 44.21 & 38.11 & 0 & 38.02 & 30.03 & 24.92 & 1.92 \\
\hline Moisture (\%) & 10.46 & 11.71 & 12.46 & 14.42 & 7.55 & 7.90 & 11.38 & 12.47 & 1.68 \\
\hline Ash (\%) & 3.14 & 3.78 & 4.51 & 5.50 & 3.22 & 3.89 & 4.60 & 5.70 & 0.24 \\
\hline Crude protein (\%) & 17.91 & 18.94 & 20.41 & 23.05 & 16.09 & 17.50 & 18.70 & 19.50 & 0.27 \\
\hline Crude fat $(\%)$ & 4.39 & 4.75 & 5.20 & 5.48 & 4.62 & 4.76 & 5.32 & 5.65 & 0.14 \\
\hline Crude fiber (\%) & 3.99 & 5.18 & 5.98 & 7.85 & 4.30 & 5.65 & 6.35 & 7.95 & 0.94 \\
\hline $\begin{array}{l}\text { Total } \\
\text { carbohydrates }(\%)\end{array}$ & 60.11 & 54.84 & 51.44 & 43.70 & 64.22 & 60.03 & 54.00 & 48.73 & 00.63 \\
\hline
\end{tabular}


Table.2 Effect of insect infestation (Bruchid) and cooking on, starch, energy, sugars, total nitrogen, non protein nitrogen, true protein and uric acid content

\begin{tabular}{|c|c|c|c|c|c|c|c|c|c|}
\hline \multirow[t]{2}{*}{ Attribute } & \multicolumn{4}{|c|}{$\begin{array}{c}\text { Uncooked (Level of Infestation } \\
\% \text { ) }\end{array}$} & \multicolumn{4}{|c|}{ Cooked (Level of Infestation \%) } & \multirow[t]{2}{*}{$\begin{array}{l}\text { CD (p } \\
\leq 0.05)\end{array}$} \\
\hline & 0 & 20 & 40 & 60 & 0 & 20 & 40 & 60 & \\
\hline $\operatorname{Starch}(\%)$ & 52.90 & 45.75 & 38.98 & 31.34 & 41.08 & 34.58 & 25.96 & 18.92 & 1.56 \\
\hline Energy $($ Kcal/100g) & 365 & 350 & 338 & 309 & 305 & 278 & 262 & 235 & 3.70 \\
\hline Total sugars $(\%)$ & 6.37 & 7.00 & 7.40 & 8.01 & 9.15 & 9.54 & 10.42 & 11.21 & 0.17 \\
\hline Reducing sugars (\%) & 0.12 & 1.07 & 2.09 & 3.69 & 0.20 & 1.44 & 2.12 & 3.64 & 0.23 \\
\hline $\begin{array}{l}\text { Non-reducing sugars } \\
(\%)\end{array}$ & 6.25 & 5.94 & 5.31 & 4.33 & 8.95 & 8.50 & 8.30 & 7.57 & 0.18 \\
\hline Total nitrogen (g/100g) & 2.85 & 3.06 & 3.24 & 3.72 & 2.64 & 2.88 & 2.98 & 3.25 & 0.14 \\
\hline $\begin{array}{l}\text { Non protein nitrogen } \\
(\mathrm{g} / \mathbf{1 0 0 g})\end{array}$ & 0.002 & 0.50 & 1.04 & 1.98 & 0.00 & 0.50 & 0.80 & 1.50 & 0.10 \\
\hline True protein $(\%)$ & 17.80 & 16.00 & 13.75 & 10.87 & 16.50 & 14.87 & 13.62 & 10.93 & 0.23 \\
\hline Uric acid (mg/100g) & 0.00 & 786.08 & 1625.67 & 3530.43 & 0.00 & 335.35 & 850.74 & 1633.12 & 520.71 \\
\hline
\end{tabular}

Table.3 Effect of cooking on NDF, ADF, Hemi cellulose, minerals and anti nutritional factors of graded levels of insect (C. chinensis) infested chick pea

\begin{tabular}{|c|c|c|c|c|c|c|c|c|c|}
\hline \multirow[t]{2}{*}{ Attribute } & \multicolumn{4}{|c|}{ Uncooked (Level of Infestation \%) } & \multicolumn{4}{|c|}{ Cooked (Level of Infestation \%) } & \multirow{2}{*}{$\begin{array}{l}\text { CD }(P \leq \\
0.05)\end{array}$} \\
\hline & 0 & 20 & 40 & 60 & 0 & 20 & 40 & 60 & \\
\hline NDF (\%) & 9.60 & 11.80 & 12.86 & 14.02 & 11.25 & 12.70 & 14.38 & 16.45 & 0.13 \\
\hline $\operatorname{ADF}(\%)$ & 7.55 & 10.66 & 12.16 & 13.74 & 9.80 & 11.65 & 13.53 & 15.80 & 0.11 \\
\hline Hemicellulose (\%) & 2.05 & 1.14 & 0.70 & 0.28 & 1.70 & 1.05 & 0.85 & 0.65 & 0.33 \\
\hline Calcium (mg/100g) & 120.25 & 137.75 & 160.75 & 230.75 & 178.32 & 183.70 & 177.19 & 225.75 & 3.32 \\
\hline Phosphorus (mg/100g) & 325.08 & 368.98 & 442.83 & 590.35 & 278.30 & 318.95 & 357.32 & 385.73 & 6.89 \\
\hline Sodium(mg/100g) & 35.50 & 47.41 & 56.35 & 70.03 & 36.55 & 52.37 & 60.30 & 70.31 & 1.30 \\
\hline Potassium (mg/100g) & 205.33 & 220.75 & 224.30 & 238.19 & 211.05 & 229.91 & 230.40 & 245.93 & 5.24 \\
\hline Copper (mg/100g) & 1.31 & 1.45 & 1.56 & 1.65 & 1.73 & 1.49 & 1.61 & 1.70 & 0.44 \\
\hline Magnesium (mg/100g) & 1.67 & 1.71 & 1.82 & 1.94 & 1.75 & 1.85 & 1.89 & 1.97 & 0.31 \\
\hline Zinc $(\mathrm{mg} / \mathbf{1 0 0 g})$ & 3.66 & 3.78 & 4.03 & 4.37 & 3.98 & 3.97 & 4.11 & 4.55 & 0.38 \\
\hline Iron $(\mathrm{mg} / \mathbf{1 0 0 g})$ & 7.28 & 7.80 & 8.97 & 9.20 & 3.85 & 5.01 & 5.16 & 5.25 & 0.31 \\
\hline Phytic acid (mg/100g) & 285.08 & 310.44 & 332.95 & 357.06 & 175.08 & 195.27 & 230.71 & 335.65 & 8.74 \\
\hline inhibitors & 291.05 & 293.98 & 295.20 & 301.30 & 132.62 & 193.63 & 242.82 & 180.89 & 12.07 \\
\hline $\begin{array}{ll}\text { Total } & \text { phosphorus } \\
(\mathrm{mg} / \mathbf{1 0 0 g}) & \end{array}$ & 325.08 & 368.98 & 442.83 & 590.35 & 181.19 & 318.95 & 357.32 & 385.73 & 6.89 \\
\hline $\begin{array}{l}\text { Phytate } \\
\text { (mg/100g) }\end{array}$ & 80.33 & 87.48 & 93.82 & 100.61 & 49.33 & 55.02 & 65.01 & 94.58 & 1.59 \\
\hline $\begin{array}{l}\text { Non-phytate Phosphorus } \\
\text { (mg/100g) }\end{array}$ & 244.75 & 281.50 & 349.01 & 489.74 & 131.86 & 263.93 & 292.31 & 291.15 & 9.11 \\
\hline
\end{tabular}


Data presented in Table 3 depicts that insect infested results in a significant $(\mathrm{P} \leq 0.05)$ increase in the NDF, ADF, Hemicelluloses, minerals and anti nutritional factors content of insect infested uncooked grains of Chick pea. Dietary fiber constituents i.e. NDF and ADF increased, with the increase in levels of infestation. But hemicelluloses content decreased, non- significantly with increase in infestation levels. Cooking of insect infested Chick pea resulted in significant $(\mathrm{p} \leq 0.05)$ increase in the NDF and ADF content, at subsequent levels of infestation, while the hemiceullose content decreased after cooking. This increase in the ADF might have been due higher insects attack at higher levels of infestation. Insects consume mainly endosperm portion, as a result husk is left behind, which is rich in fiber content. Cooking of insect infested Chick pea resulted in a further decrease in hemicelluloses content. This decrease in hemicelluloses content of infested Chick pea grains might have been due to hydrolysis of starch, carbohydrates and other nutrient components by heating. Similar results have been reported by Vidal and Frias (1992) and Mankotia (2002).

A significant decrease was noted in calcium, phosphorus and iron content of the cooked Chick pea when compared with similar uncooked counter parts where as a significant increase was noted in all other minerals at 60 percent level of infestation when compared with their uncooked counterpart. This increase in the mineral content of the insect infested Chick pea might be due to increase in insect population and also due to reason that insects consume mainly endosperm portion, as a result husk rich in minerals is left behind. Same results have been reported by Yousef $e t$ al., (1987) and Mankotia (2002).

Anti-nutritional factors phytic acid and trypsin inhibitors increased with the increase in levels of infestation of Chick pea. The maximum phytic acid content was in Chick pea at 60 per cent level $(357.06 \mathrm{mg} / 100 \mathrm{~g})$. In uncooked insect infested grains of Chick pea trypsin inhibitor ranged from 291.05 to 301.30 (TlU/g). Cooking of insect infested grains of Chick pea resulted in a slight decrease in phytic acid and trypsin inhibitor. Phytate phosphorus and non-phytate phosphorus also increased with increase in infestation levels, in both the varieties of Chick pea. The maximum amounts of phytate phosphorus and non-phytate phosphorus was in uncooked grains of Chick pea it was 100.61 and $489.74 \mathrm{mg} / 100 \mathrm{~g}$ ). Cooking resulted in decrease in phytate phosphorus and nonphytate phosphorus. Earlier, Modgil and Mehta (1997) have revealed that graded levels of insect infestation resulted an increase in the phytic acid content of Chick pea. According to them this increase was due to the increased bran in insect infested legumes and antinutritional factors are mainly present in husk portion. Cooking of insect infested Legumes resulted in a decrease in phytic acid content, which might have been due to the reason that phytic acid is a heat labile anti nutritional factor and in heat treatment phytic acid destroy during cooking. Trypsin inhibitor activity was increased in insect infected uncooked Chick pea. Similar results have been reported by Modgil and Mehta (2000). A significant decrease was noted in phytic acid, trypsin inhibitors, total phosphorus, phytate phosphorus and non-phytate phosphorus content of the uncooked Chick pea when compared with similar cooked counter parts.

In conclusion insect infestation showed an adverse effect on the physical and nutritional quality of Chick pea. Even cooking of insect infested Chick pea could not improve the quality of Chick pea. Insects $(C$. chinensis) larval and pupal stages being inside the grains, body fragments and excreta of insect made the pulse unhygienic. After cooking 
insect infested grains, only 60 per cent decrease was noted in uric acid and antinutritional factors. Insect infested Legumes should not be consumed even after cooking. The insect infested Chick pea was damaged qualitatively as well as quantitatively. Such grains should not be consumed by human beings.

\section{References}

AOAC, 2010. Official methods of analysis. Association of Official Analytical Chemists, Washington, D.C.

Clegg, K.M. 1956. The application of the anthrone reagent to the estimation of starch in cereals. Journal of Science of Food and Agriculture 7: 40.

Davis. N.T. and Reid, H. 1979. Evaluation of phytate, zinc, copper, iron and magnesium content of and availability from soya based textured vegetables. British Journal of Nutrition 41:579.

Gopalan, C, Ramasastri, B.B., Balasubramanian, Narasingha, Rao, B.S., Deosthate, Y.G. and Pant, K.C. 2010. Nutritive value of Indian foods. National Institute of Nutrition ICMR, Hydrabad, India pp. 47.

Gupta, V. 1995. Nutritional evaluation of supplementary food enriched with faba beans. M.Sc. Thesis. Himachal Pradesh Krishi Vishvavidyalaya, Palampur, India.

ICRISAT,1993. International Crop Research Institute for Semi Arid Tropics. Annual Report 1992. ICRISAT. Patancheru, India. Pp. 43-45.

Jood, S. and Kapoor, A.C. 1997. Improvement in bioavailability of minerals of chickpea and black gram cultivars through processing and cooking methods. International Joumal of Food Science and Nutrition 48: 307312.

Khader, V. 2000. A text on food storage and preservation. Kalyani Publishers pp. 4.

Kataria, A., Chauhan, B.M. and Punia, D. 1990. Effect of domestic processing and cooking methods on the content of amphidiploids (black gram $\mathrm{x}$ mung bean). Food Chemistry 36: 63-67.

Mankotia, K. 2002. Effect of soaking, sprouting and cooking on nutritional and biological quality of cowpea, moth beans and kidney beans. M.Sc. Thesis. Himachal Pradesh Krishi Vishvavidyalaya, Palampur, India.

Mankotia, K. and Modgil, R. 2012. Effect of soaking sprouting and cooking on chemical properties of Moth Beans (Vigna aconitifolia). Journal of Human Ecology 14(4): 297-299.

Mankotia, K. and Modgil, R. 2002. Effect of soaking, sprouting and cooking on physico-chemical properties of cowpea (Vigna uniguiculata). Beverage and Food World 29(12): 31-32.

Modgil, R. and Mehta, U. 1995. Effect of insect infestation $(C$. chinensis) on the physico-chemical properties of Chick pea $(C$. arietinum) during storage. Legumes Research 18(3): 157-161.

Modgil, R. and Mehta, U. 1996. Effect of graded levels of insect infestation on the chemical composition of Chick pea. Journal of Food Science and Technology 33(5): 393-396.

Modgil, R. and Mehta, U. 1997. Effect of Callosobruchus chinensis (Bruchid) infestation on anti-nutritional factors in stored Legumes. Plant Foods for Human Nutrition 50: 317-323.

R.Modgil (2000) Mineral content of insect infested stored Legumes treated with edible oils. Nahrung/ Food. 44.

Neerguard, Y.F. and Kumari, S.N. 1983. Gut bacterial flora of cow pea weevils. Current Science 52(3): 140-141.

Oser, B.L. 1971. Hawk's Physiological and Chemistry. New Delhi. Tata Mc. Grow Hill Ltd. 1047. 
O'Shea, J. and Mayure, M.E. 1962. Determination of calorific value of feed stuff by chromic oxidation. Joumal of Science of Food and Agriculture 13(10): 530.

Pellet LP and Young VR. 1980. Nutritional evaluation of protein food. UN University Publication. P 257.

Ray, D.N. and Rao, P.S. 1971. Evidence of isolation purification and some properties of trypsin inhibitor activity in Lathgrus sativus. Journal of Agriculture Food Chemistry 19: 257.

Swaminathan, M. 1977. Effect of insect infestation on weight loss, hygienic conditions, acceptability and nutritive value of food grains. Indian Journal of Nutritional Dietetics 14: 205-206.

Samuels, R. 1997. Nutritional changes in wheat during storage in different storage structures. M. Sc. Thesis. CSKHPKV, Palampur, India.

Snedecor,W., Coeharn,WG. 1968. Statistical Methods6th edn New Delhi, Oxford and
IBH Pub.

Vidal Valverde, C. and Frias, J. 1992. Legumes processing effects on dietary fibre components. Journal of Food Science 56: 1350-1352.

Van Soest, P.J. and Wine, R.H. 1967. Use of detergent in the analysis of fibrous foods, determination of plant cell constituents. Journal of Association of Official Analytical Chemistry 50: 50.

Yousef, M.M., EL-A al, M.M.A. and Shekib, L.A.E. and Ziene, H.H. 1987. Effect of dehulling, soaking and germination of chemical composition and minerals of faba bean (Vicia faba). Food Chemistry 23: 129-136.

Devi R, Modgil R, Sood A. Effect of Cooking on the Proximate Composition, Uric Acid content and Anti-Nutritional factors on insect Bruchid infested Gram at Graded Levels of Infestation. Int J Microbiol Curr Res. 2019; 1(1): 33-36.

\section{How to cite this article:}

Rajni Modgil, Ratni Devi, Archana Sood and Anupama Sandal. 2021. Physico -chemical Properties, Uric acid, Carbohydrates, Mineral, Trypsin Inhibitor Activity and Phytic Acid Content of Bruchids Infested Processed Chick Pea. Int.J.Curr.Microbiol.App.Sci. 10(02): 19261934. doi: https://doi.org/10.20546/ijcmas.2021.1002.230 